\title{
Kebijakan One-Gate System sebagai upaya meningkatkan pelayanan lalu lintas di Satpas Gresik
}

\section{One-Gate System policy as an effort to improve services in Driver's License administration unit of Gresik}

\author{
Wikha Ardilestanto ${ }^{凶}$ \\ Polres Gresik \\ Gresik, 61114, Jawa Timur, Indonesia \\ E-mail of corresponding author: wikha.ardilestanto-2016@pasca.unair.ac.id
}

\begin{abstract}
Abstrak
Munculnya berbagai kendala terhadap pelayanan lalu lintas di Satpas Gresik menimbulkan berbagai keluhan dari masyarakat, sehingga kepolisian mengeluarkan kebijakan One-Gate System. Tujuan penelitian ini adalah untuk mengkaji implementasi One-Gate System sebagai upaya meningkatkan pelayanan lalu lintas di Satpas Gresik serta mengetahui kendala atau hambatan apa saja yang muncul dalam proses pengurusan SIM di Kantor Samsat Gresik. Metode penelitian yang digunakan adalah pendekatan kualitatif. Teknik pengambilan sampel yang digunakan dalam penelitian ini adalah teknik purposive. Adapun pengumpulan data dalam penelitian ini antara lain wawancara, dokumentasi dan observasi. Hasil penelitian di lapangan menemukan bahwa implementasi OneGate System sebagai sarana meningkatkan pelayanan lalu lintas yaitu adanya sumberdaya manusia Polri yang memahami tugas pokok fungsi masing-masing, prosedur pembuatan SIM yang sederhana dan cepat, peralatan pelayanan One-Gate System lebih modern dan update, adanya kerjasama antar pelaksana One-Gate System dan indeks kepuasan masyarakat yang sangat baik. Kendala dalam proses pengurusan SIM dengan One-Gate System sebagai upaya meningkatkan pelayanan lalu lintas yaitu faktor sumberdaya manusia Satpas Polres Gresik masih ada yang belum mengikuti pendidikan kejuruan dan sertifikasi serta faktor kenyamanan dan kebersihan sarana dan prasarana.
\end{abstract}

Kata kunci: One-Gate System; indeks kepuasan masyarakat; pelayanan SIM; lalu lintas; kebijakan

\section{Abstract}

The emergence of various obstacles in services of Driver's License Administration Unit (Satpas) of Gresik results in complaints from the public, so the police decided to issue a one-gate system policy. This research aims to examine the implementation of One-Gate System as an effort to improve services of Satpas Gresik and to identify obstacles in the driver's license administration process in this One-Roof Administration System Office (Samsat) of Gresik. The study was done qualitatively using purposive. Data collection includes interviews, documentation, and observations. The study finds that the implementation of the one-gate system can improve traffic services due to: the police officers who understand the basic task of each function, a simple and fast driver's license application procedure, modern and updated one-gate system instruments, cooperation between one-gate system executants, and an excellent community satisfaction index. The study also identifies some obstacles in the implementation of the one-gate system policy: untrained and uncertified officers in Satpas Gresik, and comfort and hygiene factors of the facilities and infrastructure at the unit.

Keywords: One-Gate System; community satisfaction index; driver's license; traffic; policy

\section{Pendahuluan}

Pasal 1 ayat (4) Peraturan Kepala Kepolisian Republik Indonesia Nomor 9 Tahun 2012 tentang Surat Izin Mengemudi (selanjutnya disingkat Perkapolri tentang SIM) menyebutkan bahwa Surat Izin Mengemudi (SIM) adalah tanda bukti legitimasi kompetensi, alat kontrol dan data forensik kepolisian bagi seseorang yang telah lulus uji pengetahuan, kemampuan dan keterampilan untuk mengemudikan kendaraan bermotor di jalan sesuai dengan persyaratan yang ditentukan berdasarkan Undang-Undang Lalu Lintas dan Angkutan Jalan (Rahmat 2019).

Berdasarkan pra survei yang dilakukan oleh peneliti di Satuan Penyelenggara Administrasi SIM (SATPAS) Kepolisian Resort Gresik, pelayanan dalam pembuatan dan perpanjangan SIM masih 
kurang standar terutama menyangkut pada ujian teori dan praktek. Selain itu terdapat permasalahan lain yaitu: adanya persyaratan yang kurang jelas, waktu penyelesaian, biaya yang tidak seragam, adanya praktek pencaloan dan adanya pelayanan yang tidak nyaman.

Berbagai permasalahan tersebut didukung dengan adanya pelaporan di salah satu layanan aspirasi dan pengaduan online rakyat Gresik yang ditujukan kepada Kepolisian Republik Indonesia. Pada layanan aspirasi dan pengaduan online tersebut, tertera bahwa pengurusan SIM di Kota Gresik tidak menjadi hal yang mudah (Setiawan \& Prabawati 2019). Hal tersebut didukung dengan adanya berbagai permasalahan, yaitu: adanya antrean yang mengular sampai jalan raya, besarnya antusias masyarakat yang ingin tertib berlalu lintas tidak diimbangi dengan pelayanan yang memadai dari pihak kepolisian, banyak masyarakat yang antri dari jam 04.00 WIB pagi untuk memperoleh nomer antrian, dan kurangnya material serta mesin pencetak SIM (Pringgo 2015).

Dengan alasan tersebut kemudian masyarakat lebih memilih untuk menggunakan jasa calo untuk mendapatkan SIM tanpa perlu bersusah payah melalui berbagai ujian teori maupun praktik tersebut (Laksmita 2017). Praktik penggunaan jasa calo ini juga terjadi pada Satuan Penyelenggara Administrasi SIM Polres Gresik atau selanjutnya disebut sebagai Satpas Polres Gresik. Kehadiran calo ini juga didukung dengan kondisi dimana pada kenyataannya pengurusan atau pembuatan SIM saat ini masih belum optimal dalam hal penyaringan atau pengawasan ketat, sehingga mendorong munculnya calo-calo masuk dalam lingkungan Satpas (Permatasari 2006; Setyaningsih 2009; Suryawan 2018).

Dengan adanya praktik calo di lingkungan Satpas tersebut kemudian menghilangkan esensi dan tujuan dari SIM itu sendiri yang awalnya merupakan bukti kompetensi dari seorang pengemudi (Nursa'adah 2013). Praktik calo tersebut menjadikan seseorang dapat memiliki SIM tanpa melalui proses ujian teori dan praktik. Akibatnya, meskipun banyak pengemudi yang memiliki SIM namun tidak memiliki kompetensi maupun kualitas dari seorang pengemudi kendaraan (Fatkhuri 2018). Hal ini kemudian menjadi fatal ketika banyak terjadi kecelakaan yang diakibatkan oleh ketidakpahaman pengemudi terkait peraturan lalu lintas itu sendiri (Affandi 2016; Nastiti 2018; Anjarani 2019; Putra 2019). Sehingga praktik calo dalam proses pembuatan SIM di Satpas ini harus segera ditangani. Karena hal ini secara tidak langsung juga merupakan bagian dari kurangnya kualitas pelayanan itu sendiri (Hambali 2019).

Terkait praktek calo, hal tersebut dapat dilihat pada Program Quick Wins Polri 2015 nomor 8 di mana dilakukan crash program pelayanan masyarakat yaitu pelayanan bersih dari pencaloan. Terkait hal tersebut, adanya penerapan metode one- gate service, diharapkan dapat memperbaiki atau meningkatkan kualitas pelayanan pada pembuatan SIM di Satuan Penyelenggara Administrasi SIM (SATPAS) Kepolisian Resort Gresik.

Salah satu kebijakan yang dapat diimplementasikan dalam meningkatkan kualitas pelayanan yaitu program One-Gate System (Kristiono 2019; Juwita 2018). Sistem pelayanan terpadu satu pintu atau One-Gate System merupakan suatu usaha yang dilakukan pemerintah untuk meningkatkan kualitas pelayanan kepada masyarakat (Dwi \& Susiloadi 2017). Dalam Peraturan Menteri Dalam Negeri Nomor 24 Tahun 2006 tentang pedoman penyelenggaraan pelayanan terpadu satu pintu, sistem pelayanan terpadu satu pintu didefinisikan sebagai, "Kegiatan penyelenggaraan perizinan dan non perizinan yang proses pengelolaannya mudah dari tahap permohonan sampai dengan terbitnya dokumen dilakukan dalam satu tempat”.

Kebijakan One-Gate System ini telah diterapkan pada beberapa bidang lain sebagaimana yang telah dikaji dalam penelitian yang dilakukan oleh Dwi \& Susiloadi (2017) yaitu kebijakan One-Gate System yang diimplementasikan pada Dinas Penanaman Modal dan Pelayanan Terpadu Satu Pintu dalam Pelayanan Perizinan di Kota Surakarta. Hasil dari penelitian tersebut menunjukkan bahwa indikator kelengkapan dan kenyamanan infrastruktur belum mencapai target dengan tepat, sedangkan indikator lainnya (kesederhanaan, kejelasan, kepastian waktu, akurasi, keamaan, tanggung jawab, kemudahan akses, kedisiplinan, kesopanan dan keramahan, serta standar pelayanan minimal) telah 
diimplementasikan dengan baik. Selain itu, kebijakan One-Gate System ini juga telah diterapkan Penanaman Modal di Kabupaten Bangka sebagaimana penelitian yang dilakukan oleh Anshori et.al. (2014). Penerapan One-Gate System di Satpas Polres Gresik menggunakan dua filter masuk (Utomo, 2018). Yang pertama di portal depan harus tukar KTP untuk mendapatkan ID Card kemudian pintu masuk ke gedung pelayanan tidak bisa sembarangan orang yang mendapatkan ID Card baru bisa masuk ke Gedung pelayanan (Utomo 2018).

Berdasarkan fenomena dan hasil penelitian terdahulu yang telah dijelaskan tersebut maka penelitin tertarik untuk mengkaji lebih dalam terkait dengan penerapan dari kebijakan program One-Gate System dalam proses pembuatan SIM di Satpas Polres Gresik. Adapun judul dari penelitian ini adalah "Kebijakan One-Gate System Sebagai Upaya Meningkatkan Pelayanan Lalu Lintas di Satpas Gresik". Tujuan penelitian ini yaitu untuk mengkaji implementasi One-Gate System sebagai upaya meningkatkan pelayanan lalu lintas di Satpas Gresik dan untuk mengkaji kendala atau hambatan apa saja yang muncul dalam proses pngurusan SIM di Kantor Samsat Gresik.

Kualitas pelayanan dianggap sebagai senjata ampuh pada organisasi penyedia layanan jasa (Lewis 1988; Mawby \& Worthington 2002; Tomaževič 2017). Kualitas pelayanan menjadi pemicu keberhasilan organisasi atau perusahaan dari segala lini (Talbot 2008). Kualitas pelayanan adalah perbandingan antara pelayanan yang diharapkan pengguna dengan pelayanan yang diterimanya. Apabila pelayanan yang diterima atau dirasakan sesuai dengan yang diharapkan oleh pengguna, maka kualitas pelayanan dipersepsikan baik dan memuaskan. Apabila jasa atau pelayanan yang diterima melampaui harapan pengguna maka kualitas pelayanan dipersepsikan sebagai kualitas ideal. Tetapi sebaliknya apabila pelayanan yang diterima lebih rendah dari yang diharapkan maka kualitas pelayanan dipersepsikan buruk. Pada dasarnya, kualitas pelayanan harus dimulai dari kebutuhan pengguna dan berakhir dari tanggapan pengguna (Samosir 2005).

Kualitas pelayanan adalah sebuah tingkat keunggulan dan pengendalian terhadap tingkat keunggulan tersebut, dalam rangka memenuhi keinginan pengguna (Ruiz \& Hummer 2017; Homberg et al. 2019). Baik buruknya kualitas pelayanan tidak dapat ditentukan oleh pemberi jasa. Pengguna memiliki kekuasaan untuk menentukan apakah layanan yang diterima sudah sesuai, melebihi, atau tidak sesuai dengan harapan (Van de Walle 2018). Pada kondisi tersebut, pihak penyedia layanan memiliki kepentingan untuk mengetahui harapan pengguna terkait dengan pelayanan yang diberikan. Apabila harapan pengguna terpenuhi atau dilebihi, maka kualitas pelayanan dapat dikatakan baik (Kaihatu et al. 2015).

Undang-Undang pelayanan publik menegaskan bahwa standar pelayanan adalah tolak ukur yang dipergunakan sebagai pedoman penyelenggaraan pelayanan dan acuan penilaian kualitas pelayanan sebagai kewajiban dan janji penyelenggara kepada masyarakat dalam rangka pelayanan yang berkualitas, cepat, mudah terjangkau dan terukur. Pelayanan yang diberikan kepada masyarakat selalu menuntut pelayanan publik yang berkualitas dari aparat birokrasi yang dilakukan secara transparan dan akuntabilitas (Rahmat 2019). Asas atau pedoman penyelenggara pelayanan publik diatur dalam Pasal 4 UU Nomor 25 Tahun 2009, yang terdiri dari (Hasjimzum 2014): (1) Kepentingan umum; menunjukkan bahwa pemberian pelayanan tidak boleh mengutamakan kepentingan pribadi atau golongan; (2) Kepastian hukum; menunjukkan bahwa jaminan terwujudnya hak dan kewajiban dalam penyelenggaraan pelayanan; (3) Kesamaan hak; menunjukkan bahwa pemberian pelayanan tidak membedakan suku, ras, agama, golongan, gender dan status atau strata ekonomi.

Pasal 1 Ayat 6 Peraturan Kepala Kepolisian Negara Republik Indonesia Nomor 9 Tahun 2012 "Pengemudi adalah orang yang mengemudikan Ranmor di Jalan yang telah memiliki SIM". SIM ini merupakan salah satu indikator kualitas mengemudi dari seorang pengemudi. Dapat dikatakan demikian karena pada proses untuk mendapatkan SIM ini seorang calon pengemudi harus menjalani beberapa ujian baik tulis maupun ujian praktik. Sebagaimana telah dijelaskan sebelumnya bahwa, pengetahuan seorang pengemudi terkait dengan tanda-tanda dan opersaional lalu lintas dapat teruji dengan adanya ujian tulis. 


\section{Metode Penelitian}

Pendekatan yang digunakan dalam penelitian ini menggunakan pendekatan kualitatif. Sugiyono (2012) menjelaskan bahwa penelitian kualitatif merupakan metode penelitian yang digunakan untuk meneliti pada kondisi obyek alamiah dimana peneliti adalah sebagai instrumen kunci, teknik pengumpulan dengan triangulasi, analisis data bersifat induktif dan hasil penelitian lebih menekankan makna daripada generalisasi. Jenis penelitian yang digunakan dalam penelitian ini deskriptif. Deskriptif adalah penelitian yang dilakukan dengan mengumpulkan semua data kunci berupa kata-kata, gambar dan kutipan- kutipan data untuk memberikan gambaran penyajian laporan penelitian. Data- data tersebut dapat berasal dari naskah wawancara, kutipan lapangan, foto, videotape, dokumen pribadi catatan atau memo dan dokumen resmi lainnya. Selanjutnya dilakukan analisis data terhadap data-data tersebut dengan menelaah secara satu demi satu (Moleong 2011). Penelitian ini berfokus pada penerapan One-Gate System dalam meningkatkan kualitas pelayanan lalu lintas, khususnya dalam pembuatan SIM.

Informan penelitian merupakan orang yang memiliki informasi tentang penelitian. Adapun informan dalam penelitian ini adalah: (1) Kanit regident Satlantas Polres Gresik; (2) Baur SIM Satlantas Polres Gresik; (3) Tiga Anggota Satlantas Polres Gresik; (4) Pemohon SIM. Sementara itu, nalisis data merupakan proses mengatur urutan data, mengorganisasikannya ke dalam suatu pola, kategorisasi dan satuan uraian dasar. Analisis data dilakukan untuk mengkaji dan mengolah data yang telah terkumpul agar memperoleh simpulan yang sesuai dengan tujuan penelitian. Teknik analisis data yang digunakan dalam penelitian ini adalah model analisis deskriptif. Teknis analisis data dengan model analisis deskriptif (Miles \& Huberman 2007 dalam Sugiyono 2012:430-438).

\section{Hasil dan Pembahasan}

\section{Gambaran proses penerbitan SIM di Polres Gresik}

Surat Izin Mengemudi (SIM) merupakan alat atau dokumen registrasi dan identifikasi kepada pengemudi yang dibuat dari Polri, dengan memperhatikan syarat-syarat yang telah ditentukan seperti sehat jasmani dan rohani, memahami peraturan lalu lintas dan cakap mengemudikan kendaraan bermotor (Indahingwati 2019). Pasal 1 ayat (4) Peraturan Kepala Kepolisian Republik Indonesia Nomor 9 Tahun 2012 Tentang Surat Izin Mengemudi menyebutkan bahwa Surat Izin Mengemudi (SIM) adalah suatu bukti dalam bentuk dokumen atau alat resmi dari kepolisian terkait pengemudi dan kelengkapan dalam mengendarai kendaraan bermotor.

"Untuk diakui oleh negara pengemudi harus memiliki SIM, ini demi keamanan dan kenyamanan segala hal ihwal mengenai penggunaan kendaraan bermotor"

Berdasarkan wawancara tersebut, dapat diartikan bahwa kepemilikan SIM untuk pemilik kendaraan bermotor wajib, karena hal tersebut merupakan tanda diakui oleh negara atas kemampuannya dalam mengendarai kendaraan bermotor tersebut.

Hakikatnya, wewenang dalam memberikan surat izin kendaraan bermotor hanya boleh dikeluarkan oleh Polri. Hal ini sesuai dengan pasal 15b UU No. 2 Tahun 2002 tentang Kepolisian Negara Republik Indonesia. Kemudian, sebuah Surat Izin Mengemudi (SIM) sendiri pada umumnya harus harus memuat berbagai hal terkait identitas pengemudi, yaitu nama, tempat tanggal lahir, alamat, pekerjaan, tinggi badan, sidik jari, tanggal berakhir masa berlaku sampai pas foto pengemudi/pemilik. Salah satu informan menyatakan sebagai berikut:

\footnotetext{
"Untuk membuat SIM lembaga berwenang mengeluarkan SIM hanya Polri, ini mencakup keseluruhan data pemohon seperti identitas pengemudi, yaitu nama, tempat tanggal lahir, alamat, pekerjaan, tinggi badan, sidik jari, tanggal berakhir masa berlaku sampai pas foto pengemudi/pemilik"
} 
Tujuan dari pembuatan Surat Izin Mengemudi (SIM) adalah terciptanya kondisi tertib administratif di masyarakat yang pada akhirnya bermuara pada tertibnya masyarakat dalam berkendara di jalanan (Dharma 2014; Herlina 2017). Hal tersebut terjadi karena Surat Izin Mengemudi (SIM) merupakan legalitas atau tanda pemegang Surat Izin Mengemudi (SIM) telah memiliki izin untuk mengemudikan kendaraan tertentu.

\section{Adanya kerja sama antar pelaksana One-Gate System}

Setiap kegiatan atau aktivitas pelayanan dilakukan oleh personel yang telah ditentukan dan memberikan arahan dan contoh tentang bagaimana melaksanakan suatu kegiatan dalam proses penerbitan SIM tersebut (Diansari \& Lestari 2017). Dari hasil pengamatan, peneliti tidak menemukan lagi penerbitan secara manual yang ada semua berbasis IT melalui proses sim online. Pelayanan berjalan dengan lancar dan berkualitas apabila setiap pihak yang berkepentingan dengan pelayanan memiliki adanya kepentingan yang sinergi, dalam menyelesaikan atau mengurus atau memiliki komitmen yang sama terhadap pelayanan. Hal ini juga dibenarkan oleh salah satu Informan sebegai berikut:

"Setiap pihak dalam unit pelayanan sangat saling terkait, sudah terjalin kerjasama yang baik dari petugas maupun masyarakat. Dan Satpas Polres Gresik dilatih untuk saling bekerjasama, kalau tidak ada kerja sama wah repot pastinya, karena sudah ada kerja sama inilah pelayanan penerbitan SIM online dapat terwujud dengan maksimal"

Pernyataan serupa juga dinyatakan oleh informan sebagai berikut:

"Komitmen untuk saling mengerti saja, memang ditingkatkan. Polisi mau melayani dengan sepenuh hati, kerjasama antar bagian juga harus menjadi perhatian setiap personel, agar pelayanan semakin baik"

Pernyataan di atas, menjelaskan adanya kerja sama dari masing-masing personel sudah terjalin dalam pelayanan pada setiap bagian di Satpas Polres Gresik sehingga diharapkan dapat mewujudkan pelayanan terhadap masyarakat secara maksimal.

Menurut salah satu masyarakat Kabuepaten Gresik yang melakukan permohonan pembuatan SIM menyatakan sebagai berikut:

"Pelayanan sudah baik, karena setiap bagian saya lihat saling bekerjasama, dan petugas juga saling membantu untuk tetap melayani masyarakat dengan cepat"

Berdasarkan pernyataan di atas, telah membenarkan bahwa adanya kerjasama yang dilakukan oleh petugas Satpas Polres Gresik saat memberikan pelayanan pembuatan SIM.

\section{Indeks Kepuasan Masyarakat yang baik}

Pemerintah sebagai penyedia jasa layanan publik, harus senantiasa meningkatkan kualitasnya. Salah satu upaya untuk meningkatkan kualitas pelayanan publik, sebagaimana diamanatkan dalam Undang-undang Republik Indonesia Nomor 25 Tahun 2000 tentang Program Pembangunan Nasional (PROPENAS), perlu disusun indeks kepuasan masyarakat sebagai tolok ukur untuk menilai tingkat kualitas pelayanan. Pemerintah disini juga salah satunya adalah Kepolisian Negara Republik Indonesia. Satpas Polres Gresik merupakan bagian dari institusi yang berkewajiban menyelenggarakan pelayanan publik terkait dengan kebutuhan penerbitan Surat Ijin Mengemudi (SIM). Hal ini disampaikan oleh narasumber sebagai berikut:

\footnotetext{
"Untuk selalu menjadi terpercaya, kepolisian terus memperbaiki diri, dan tipe pelayanannya. Ini juga dilakukan oleh Satpas Polres Gresik. Tidak mudah melakukan reformasi sistem pelayanan, namun kami terus berusaha maksimal"
} 
Indeks Kepuasan Masyarakat (IKM) adalah data dan informasi tentang tingkat kepuasan masyarakat yang diperoleh dari hasil pengukuran secara kuantitatif dan kualitatif atas pendapat masyarakat dalam memperoleh pelayanan dari aparatur penyelenggara pelayanan publik dengan membandingkan antara harapan dan kebutuhannya (Gaussyah et al. 2015). Di samping itu data IKM dapat menjadi bahan penilaian terhadap unsur pelayanan yang masih perlu perbaikan dan menjadi pendorong setiap unit penyelenggara pelayanan untuk meningkatkan kualitas pelayanannya (Noor \& Agustina 2019). Penyusunan Indeks Kepuasan Masyarakat dimaksudkan sebagai acuan bagi Unit Pelayanan instansi pemerintah untuk mengetahui tingkat kinerja unit pelayanan secara berkala sebagai bahan untuk menetapkan kebijakan dalam rangka peningkatan kualitas pelayanan publik selanjutnya. Bagi masyarakat, Indeks Kepuasan Masyarakat dapat digunakan sebagai gambaran tentang kinerja pelayanan unit yang bersangkutan.

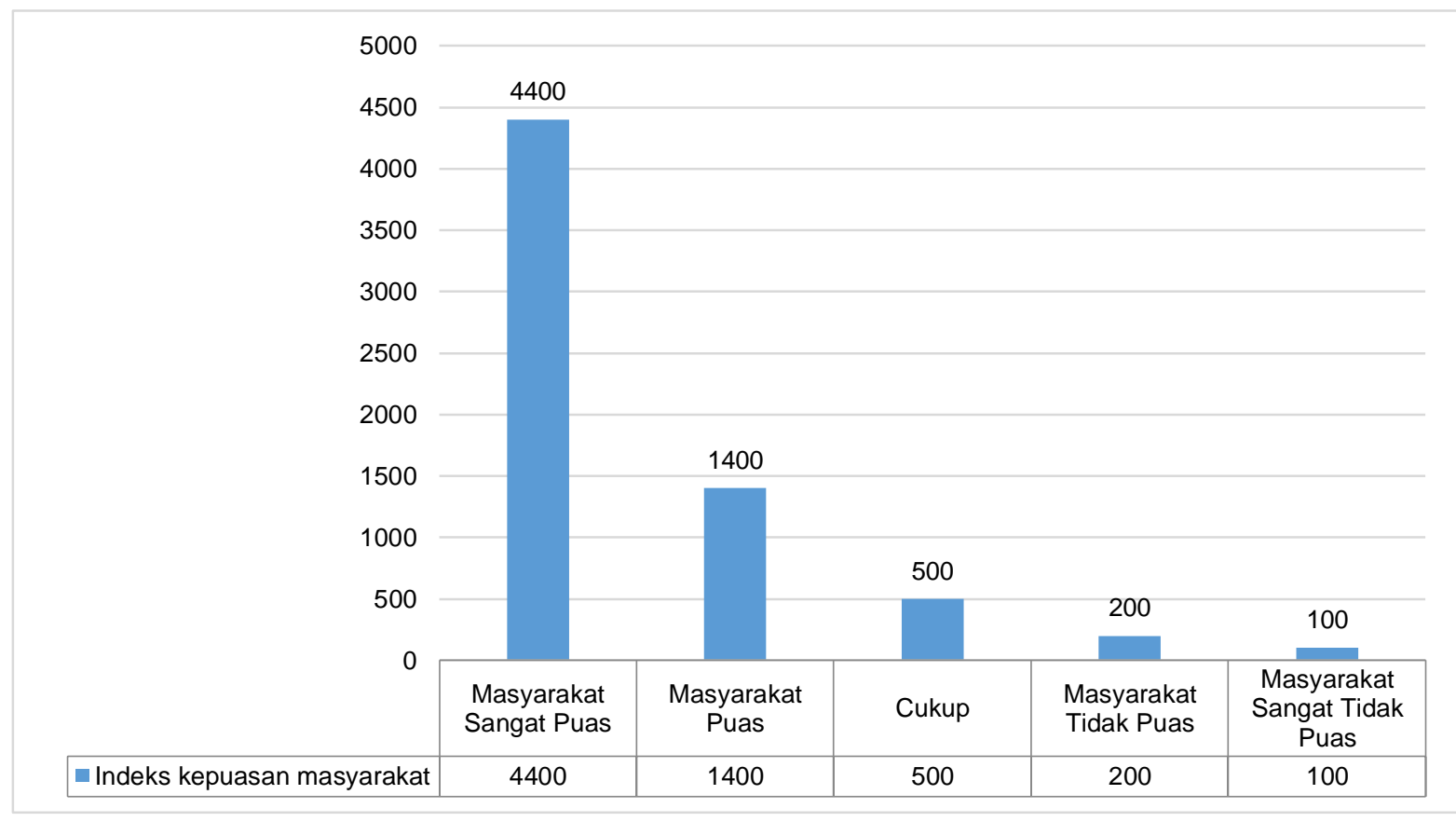

Gambar 1.

Grafik kepuasan masyarakat

Sumber: Korlantas Polri (2018)

Pada gambar 1, dapat dilihat bahwa indeks pelayanan masyarakat di Polres Gresik sudah baik dan berada pada peringkat ketiga setelah Polres Buru dan Polres Gunung Mas.

Tabel 1.

Indeks kepuasan masyarakat

Rangking berdasarkan Polres

\begin{tabular}{lllllll}
\hline No. & \multicolumn{1}{c}{ Polres } & $\begin{array}{c}\text { Prosedur } \\
\text { Layanan }\end{array}$ & $\begin{array}{c}\text { Kompetensi } \\
\text { Petugas }\end{array}$ & $\begin{array}{c}\text { Perilaku } \\
\text { Petugas }\end{array}$ & Total & Tipe Polda \\
\hline 1 & Polres Buru & 92,30 & 94,83 & 96,66 & 94,90 & A \\
2 & Polres Gunung Mas & 91,69 & 95,26 & 96,09 & 94,56 & A \\
3 & Polres Gresik & 92,25 & 91,62 & 92,74 & 92,52 & A \\
4 & $\begin{array}{l}\text { Polres Lampung } \\
\text { Timur }\end{array}$ & & 80,00 & 92,31 & 90,72 & A \\
5 & Polres Batang & 90,74 & 92,11 & 92,89 & 90,72 & A \\
6 & $\begin{array}{l}\text { Polres Konawe } \\
\text { Selatan }\end{array}$ & 89,74 & 89,54 & 90,67 & 90,37 & B \\
7 & Polres Pesawaran & 89,18 & 89,48 & 89,95 & 90,36 & A \\
\hline & Sumber: https://www.jpnn.com/news/polres-gresik-raih-peringkat-ketiga-dalam-pelayanan-sim
\end{tabular}


Pada tabel 1 dapat dilihat bahwa indeks kepuasan masyarakat berdasarkan Polres menunjukkan bahwa Polres Buru mendapat indeks paling banyak. Artinya, semakin tinggi total indeks kepuasan masyarakat maka kepuasan masyarakat terhadap Polres semakin meningkat.

\section{Kendala dalam proses pengurusan SIM dengan One-Gate System sebagai upaya meningkatkan pelayanan lalu lintas kualitas dan kompetensi Sumber Daya Manusia Satpas Polres Gresik}

Peserta pemohon SIM lulus ujian praktik, yang bersangkutan dapat melanjutkan ke ruang produksi untuk cetak SIM dan selanjutnya SIM tersebut diserahkan kepada pemohon. Namun bagi peserta pemohon SIM tidak lulus maka disarankan untuk kembali setelah 14 hari dan melakukan ujian praktik SIM kembali. Dengan demikian, maka dapat dikatakan bahwa kualitas dan kompetensi pengemudi dapat dilihat dari adanya SIM yang dimilikinya. Hal ini sebagaimana salah satu fungsi dari SIM yang dijelaskan dalam Pasal 86 Ayat 1 Undang- Undang Lalu Lintas dan Angkutan Jalan sebagai berikut "Surat Izin Mengemudi berfungsi sebagai bukti kompetensi mengemudi". Dengan adanya kualitas pengemudi di jalan raya ini dapat juga terlihat dari terciptanya ketertiban, kedisiplinan, kelancaran, keamanan, kenyamanan dan keselamatan lalu lintas secara keseluruhan (Noviandi et al. 2017).

Terwujudnya perubahan aspek kultural dimulai dari bagaimana Polri itu sendiri membangun sistem SDM secara terpadu dan berkesimbungan, serta bukan hanya menuntut aparatur pelaksanaannya bekerja secara professional namun para penentu strategi kebijakan SDM Polri pun harus bertindak di atas dasar profesionalisme yang objektif mengesampingkan hal-hal yang bersifat subjektif (Siregar 2016). Menurut salah satu informan menyatakan sebagai berikut:

"Sebagian besar dari personel unit regident masih belum mengikuti dikjur maupun sertifikasi, hal ini tentu berdampak dengan kemampuan petugasnya, karena ilmu yang didapat selama ini masih berdasarkan turunan dari senior-senior baik yang sudah dikjur atau sertifikasi dan dari SOP saja"

Terdapat faktor yang mempengaruhi kinerja personil unit Regident Satlantas di Polres Gresik dalam proses penerbitan SIM yaitu personel belum mengikuti dikjur maupun sertifikasi. Hal tersebut tentunya mempengaruhi kemampuan petugasnya. Meskipun telah mengikuti SOP, namun alasan pelaksanaan dikjur akan lebih membantu dalam pelaksanaan tugasnya. Pernyataan informan lainnya menyatakan sebagai berikut:

"Belum semua mampu melaksanakan tugas dengan baik, karena terkendala pengetahuan karena belum semua personel yang mendapatkan sertifikasi dan dikjur regident pengemudi. Kalau sudah dikjur kita kan lebih teliti dan lebih pede karena sudah jelas dapat ilmunya"

Informan di atas menjelaskan jika salah satu kendala yang mempengaruhi kinerja personel adalah belum mengikuti dikjur dan sertifikasi, sehingga mempengaruhi kinerja petugas. Kemudian informan lainnya menyatakan:

"Perbedaan personel yang sertifkasi dan dikjur dengan yang belum adalah: Dalam hal ketelitian, yang sudah dikjur dan sertifikasi lebih teliti dalam artian sudah lebih paham karena ilmu yang dimiliki sudah baik, prosedural serta ilmunya sudah lebih up to date."

Sejalan dengan pernyataan tersebut, seharusnya setiap personel sudah dikjur dan apabila memungkinkan harus sertifikasi, hal ini terkait dengan peningkatan SDM dan mewujudkan keinginan Polri untuk melaksanakan tugas dan fungsi secara profesional. Namun, personel satpas masih banyak yang belum dikjur dan sertifikasi. Kemudian, informan juga melanjutkan pernyataan sebagai berikut:

"Untuk meningkatkan SDM sendiri biasanya dilakukan dikjur, sertifikasi, pelatihan yang dilaksanakan oleh Bag Sumda. Dan untuk analisa dan evaluasi dilaksanakan setiap hari pada saat apel pagi. Ini rutin dan berkala dilakukan, demi pelayanan yang prima”

Berdasarkan beberapa perihal di atas, dapat disimpulkan bahwa hakikatnya kinerja Satpas Polres Gresik, telah mengalami peningkatan karena menurut indeks penilaian masyarakat kinerja petugas 
sudah baik. Namun permasalahan yang dianggap masih perlu diperhatikan adalah petugas yang belum sertfikasi dan dikjur. Akan tetapi, hal rutin yang sudah dilaksanakan oleh Satpas Polres Gresik yaitu pelatihan oleh Bag Sumda dan analisa serta evaluasi setiap hari pada saat apel pagi.

Dalam tulisan Idris (2012) menjelaskan bahwa manajemen sumber daya manusia harus menjadi pion perubahan praktik manajemen dalam lembaga, karena MSDM yang mempunyai peran strategis dalam menyusun struktur organisasi di suatu lembaga, membangun budaya organisasi, menyusun strategi staffing, menyusun program pelatihan dan pengembangan, menyusun sistem penilaian pegawai dan penghargaan pegawai.

Hasil penelitian Budiarti et al. (2015) menemukan bahwa karyawan yang tidak mempunyai pengetahuan yang cukup mengenai pekerjaannya akan mengakibatkan kurang maksimal saat kerja. Oleh karena itu, supaya dihasilkan sumber daya manusia yang mempunyai kemampuan yang berkualitas maka diperlukan adanya pendidikan, pelatihan, dan pengembangan (Haiti 2018). Penelitian tersebut, juga didukung oleh hasil temuan Irzal et al. (2017), di mana menyatakan bahwa proses pelatihan dan pengembangan bagi pekerja yang meningkat akan mempengaruhi kinerja perusahaan agar lebih efektif dan melahirkan solusi terhadap tantangan yang ditargetkan perusahaan demi kepentingan publikasi informasi ke publik serta mutu pelayanan yang baik. Berdasarkan penelitian yang telah dilakukan menunjukkan bahwa hakikatnya kinerja Satpas Polres Gresik, telah mengalami peningkatan karena menurut indeks penilaian masyarakat kinerja petugas sudah baik. Namun permasalahan yang dianggap masih perlu diperhatikan adalah petugas yang belum sertfikasi dan dikjur. Akan tetapi, hal rutin yang sudah dilaksanakan oleh Satpas Polres Gresik yaitu pelatihan oleh Bag Sumda dan analisa serta evaluasi setiap hari pada saat apel pagi.

\section{Faktor kenyamanan dan kebersihan sarana dan prasarana}

Kondisi peralatan, gedung dan peralatan fisik adalah merupakan bentuk dari bukti nyata dari kemungkinan akan tingginya kualitas pelayanan yang diberikan oleh Satpas Polres Gresik kepada masyarakat. Hasil observasi menunjukkan bahwa sarana dan prasarana di Polres Gresik, sudah lengkap. Akan tetapi, faktor kenyamanan lingkungan di Satpas Polres Gresik masih perlu ditingkatkan, hal ini demi meningkatnya pelayanan terhadap pemohon SIM. Hal ini dinyatakan oleh informan, yaitu sebagai berikut:

"Walau sudah baik, namun petugas Satpas Polres Gresik tetap harus menerima pelatihan pemanfaatan teknologi serta pemeliharaan sarpras yang baik, terutama pada kebersihan dan kenyamanan ruangan."

Pelayanan pembuatan SIM di Satpas Polres Gresik dinilai sudah baik, namun hal yang masih perlu menjadi perhatian dalam faktor sarana dan prasarana adalah unsur kebersihan dan kenyamanan ruangan. Kenyamanan lingkungan adalah salah satu hal yang krusial bagi pelaksanaan pelayanan publik. Menurut salah satu informan menjelaskan sebagai berikut:

"Kadang masih kurang nyaman, terlebih kalau antriannya panjang, kursi yang tersedia tidak mencukupi, sehingga kita harus berdiri, terlebih id card nya harus antri juga."

Berdasarkan pernyataan tersebut, dapat diartikan apabila Satpas Polres Gresik masih kurang nyaman terkait kebersihan dan kenyamanan ruangan, terlebih lagi apabila antriannya meningkat. Metode OneGate System menuntut pemberi layanan untuk bersikap disiplin, sopan dan santun, ramah serta memberikan pelayanan dengan ikhlas. Pelayanan satu pintu (One-Gate System) dalam perijinan merupakan perombakan dari sistem perijinan yang diberlakukan sebelumnya yang dirasa ribet oleh masyarakat karena melibatkan banyak teknis. Hal ini sejalan dengan Peraturan Menteri Dalam Negeri Nomor 24 Tahun 2006 tentang Pedoman Penyelenggaraan Pelayanan Terpadu Satu Pintu, yang menjelaskan tujuan dari pelayanan satu pintu adalah: a) meningkatankualitas layanan publik; dan b) memberikan akses yang lebih luas kepada masyarakat untuk memperoleh pelayanan publik. Peningkatan pelayanan publik juga diukur dengan kenyamanan lingkungan/area pelayanan lalu lintas. 
Kenyamanan lingkungan adalah salah satu hal yang krusial bagi pelaksanaan pelayanan publik. Bukti fisik dalam kualitas layanan adalah bentuk aktualisasi nyata secara fisik dapat terlihat atau digunakan oleh pegawai sesuai dengan penggunaan dan pemanfaatannya yang dapat dirasakan membantu pelayanan yang diterima oleh orang yang menginginkan pelayanan, sehingga puas atas pelayanan yang dirasakan, yang sekaligus menunjukkan prestasi kerja atas pemberian pelayanan yang diberikan. Berarti setiap orang khususnya masyarakat harus mendapatkan pelayanan pembuatan SIM secara jelas dapat merasakan manfaat dari bukti fisik yang disediakan oleh Satpas Polres Gresik, baik itu berupa kerapian, kebersihan dan kelengkapan sarana dan prasarana pelayanan yang tersedia dimasing-masing tempat pelayanan pembuatan SIM. Pada penelitian ini telah ditemukan apabila Satpas Polres Gresik masih kurang nyaman terkait kebersihan dan kenyamanan ruangan, terlebih lagi apabila antriannya meningkat. Pelayanan pembuatan SIM di Satpas Polres Gresik dinilai sudah baik, namun hal yang masih perlu menjadi perhatian dalam faktor sarana dan prasarana adalah unsur kebersihan dan kenyamanan ruangan.

\section{Simpulan}

Implementasi One-Gate System sebagai sarana meningkatkan pelayanan lalu lintas yaitu adanya sumber daya manusia Polri yang memahami tugas pokok fungsi masing-masing, prosedur pembuatan SIM yang sederhana dan cepat, peralatan pelayanan One-Gate System lebih modern dan update, adanya kerjasama antar pelaksana One-Gate System dan indeks kepuasan masyarakat yang sangat baik; Kendala dalam proses pengurusan SIM dengan One-Gate System sebagai upaya meningkatkan pelayanan lalu lintas yaitu faktor sumber daya manusia Satpas Polres Gresik masih ada yang belum dikjur dan sertifikasi dan faktor kenyamanan dan kebersihan sarana dan prasarana. Selain itu, perlu diadakan penambahan jumlah personel yang melaksanakan DIKJUR dan Sertifikasi. Adapun personel yang DIKJUR sebaiknya diarahkan sesuai dengan tugas dan fungsinya sehari-hari agar lebih maksimal. Dan untuk Sertifikasi agar lebih efektif dan efisien diadakan di Polda setempat agar personel yang disertifikasi jumlahnya dapat diperbanyak; Menambahkan fasilitas Satpas Polres Gresik diantaranya tempat duduk di ruangan pengisian formulir untuk kenyamanan dan kecepatan pelayanan guna memaksimalkan penerapan metode One-Gate System.

\section{Daftar Pustaka}

Affandi YM (2016) Penegakan hukum atas kewajiban menunjukkan surat kelengkapan bermotor saat penindakan oleh kepolisian lalu lintas. Jurnal Novum 3 (3):166-173.

Anjarani KE (2019) Penyelesaian kecelakaan lalu lintas pelaku anak. Jurnal Sosiologi Dialektika 14 (2):68-75.

Anshori YTE, Enceng \& A Hidayat (2014) Implementasi pelayanan perizinan terpadu satu pintu. Jurnal Ilmu Administrasi Negara 12 (4).

Dharma A (2014) Identifikasi kecelakaan lalu lintas (Studi kasus Jalan Dalu-Dalu sampai Pasir Pengaraian). Jurnal Mahasiswa Teknik 1 (1).

Diansari M \& Larasati E (2017) Analisis kualitas pelayanan Surat Ijin Mengemudi kendaraan motor (SIM C) di Polres Semarang 2016. Journal of Public Policy and Management Review 6 (2):112126.

Dwi G \& P Susiloadi (2017) Manajemen pelayanan terpadu satu pintu pada Dinas Penanaman Modal dan Pelayanan Terpadu Satu Pintu dalam pelayanan perizinan di Kota Surakarta. Jurnal Wacana Publik 1 (1).

Fatkhuri F (2018) Korupsi dalam birokrasi dan strategi pencegahannya. Jurnal Ilmiah Manajemen Publik dan Kebijakan Sosial 1 (2):65-76.

Gaussyah M, Damanik I, Muhammad I \& Bakhry S (2015) Mewujudkan Polri yang profesional melalui penguatan tata kelola. Indeks Tata Kelola Kepolisian Negara Republik Indonesia 2015.

Haiti FA (2018) Peran anggota Satuan Reserse Kriminal dalam menanggulangi kejahatan jalanan. Jurnal Sosiologi Dialektika 13 (2):141-151.

Hambali B (2019) Perspektif Pungutan liar pada pelayanan SSB. Jurnal Litbang POLRI 22 (2):75-133. 
Herlina H (2017) Faktor yang mendukung pelayanan pembuatan Surat Izin Mengemudi (SIM) di wilayah Kepolisian Resort Kota Besar (Polrestabes) Surabaya. JPAP: Jurnal Penelitian Administrasi Publik 3 (2).

Homberg F, Vogel R \& Weiherl J (2019) Public service motivation and continuous organizational change: Taking charge behaviour at police services. Public administration 97 (1):28-47.

Indahingwati A (2019) Kepuasan konsumen dan citra institusi kepolisian pada kualitas layanan SIM corner di Indonesia. Jakarta: CV Jakad Media Publishing.

Juwita A (2018) Optimalisasi SIM online sebagai strategi untuk mewujudkan pelayanan prima pada kantor Satpas Jember. Airlangga Development Journal 2 (2).

Kristiono T (2019) Penerapan Inovasi dalam Meningkatkan Kualitas Pelayanan Publik (Studi Deskriptif Tentang Penerapan SIM Keliling dalam Rangka Peningkatan Kualitas Pelayanan Publik di Kantor Pelayanan Surat Ijin Mengemudi Satlantas Polres Kediri Kota). Thesis: Universitas Airlangga.

Laksmita AHM (2017) Rasionalitas pengguna jasa calo dalam pengurusan SIM baru di Polres Sidoarjo. Paradigma: Jurnal Online Mahasiswa S1 Sosiologi UNESA 5 (1).

Lewis BR (1988) Customer care in service organisations. International Journal of Operations \& Production Management.

Mawby RC \& Worthington S (2002) Marketing the police-from a force to a service. Journal of Marketing Management 18 (9-10):857-876.

Nastiti FA (2018) Hubungan antara kepemilikan SIM C dan keikutsertaan dalam tes pembuatan SIM dengan pengetahuan berkendara dan kecelakaan lalu lintas di Kabupaten Sidoarjo. The Indonesian Journal of Public Health 12 (2):167-178.

Noor S \& Agustina T (2019) Pengaruh kepemimpinan, motivasi kerja, dan kepuasan kerja terhadap kinerja personil Polisi Bidokkes Polda Kalimantan Selatan. Relevance: Journal of Management and Business 2 (2).

Noviandi AA, Rohman RI, Hartanti \& Ningrum PT (2017) Faktor yang mempengaruhi perilaku mengemudi tidak aman pada sopir bus trayek Jember Kencong Lumajang (Influence factor of unsafe driving on bus driver Jember- Kencong Lumajang route). Jurnal Kesehatan 5 (2).

Nursa'adah R (2013) Pengaruh simplifikasi prosedur pelayanan pelanggan terhadap tingkat kepuasan pelanggan pelayanan perpanjangan Surat Ijin Mengemudi (SIM) di SIM Corner Kota Surabaya. Jurnal Kebijakan dan Manajemen Publik 1 (1):20-26.

Permatasari FDI (2006) Kualitas Pelayanan di Kantor Urusan SIM Satlantas Polwiltabes Surabaya. Theses: Universitas Airlangga Surabaya.

Pringgo Y (2015) Kualitas pelayanan perpanjangan pajak melalui layanan publik STNK Keliling di Gersik. Jurnal Kebijakan dan Manajemen Publik 3.

Putra KAY (2019) Penanganan terhadap kecelakaan lalu lintas di Kota Probolinggo. Jurnal Sosiologi Dialektika 14 (1):59-67.

Rahmat DA (2019) Disparitas penerbitan Surat Izin Mengemudi sebagai pemenuhan hak bagi penyandang tunarungu. Jurnal Sosiologi Dialektika 14 (1):26-33.

Ruiz J \& Hummer D (2017) Handbook of police administration. UK: Routledge.

Setiawan BS \& Prabawati I (2019) Efektivitas pelaksanaan aplikasi Go Sigap di Kepolisian Resor Gresik. Publika 6 (9).

Setyaningsih IR (2009) Kualitas Pelayanan di Kantor Urusan SIM Satlantas Polres Sragen. Theses: Universitas Sebelas Maret Surakarta.

Siregar SN (2016) Tinjauan kritis reformasi kultural Polri (1999-2012). Jurnal Penelitian Politik 11 (1):18.

Suryawan DK (2018) Kualitas pelayanan perpanjangan Surat Izin Mengemudi (SIM) golongan C. Majalah Ilmiah DIAN ILMU 15 (1).

Talbot C (2008) Measuring Public Value. London: The Work Foundation.

Tomaževič N, Tekavčič M \& Peljhan D (2017) Towards excellence in public administration: organisation theory-based performance management model. Total Quality Management \& Business Excellence 28 (5-6):578-599.

Van de Walle S (2018) Explaining citizen satisfaction and dissatisfaction with public services. In The Palgrave handbook of public administration and management in Europe (pp. 227-241). London: Palgrave Macmillan. 